\title{
PERBANDINGAN MODEL PROBLEM BASED LEARNING DAN INKUIRI TERBIMBING TERHADAP KETERAMPILAN BERPIKIR KRITIS SISWA
}

\author{
Tiya Rahmawati ${ }^{\mathbf{1}^{*}}$, Lisa Utami ${ }^{\mathbf{1}}$ dan Fitri Refelita ${ }^{\mathbf{1}}$ \\ ${ }^{1}$ Program Studi Pendidikan Kimia, Fakultas Tarbiyah dan Keguruan, Universitas Islam Negeri \\ Sultan Syarif Kasim Riau, JL. H.R Soebrantas No.155 KM.15 Simpang Baru Panam, \\ Pekanbaru, 28293, Indonesia \\ *E-mail: tiyarahmawati2017@gmail.com
}

\begin{abstract}
ABSTRAK
Penelitian ini bertujuan untuk membandingkan efektivitas model pembelajaran problem based learning dan inkuiri terbimbing terhadap keterampilan berpikir kritis siswa kelas XI MS SMA Negeri Plus Provinsi pada mata pelajaran kimia, khususnya materi koloid. Penelitian ini merupakan penelitian kuasi eksperimen dengan rancangan posttest only control group design. Sampel dalam penelitian ini adalah kelas XI MS 1 sebagai kelas eksperimen 1 dan kelas XI MS 3 sebagai kelas eksperimen 2. Analisis data akhir pada penelitian ini menggunakan uji-t. Hasil penelitian menunjukkan adanya perbedaan signifikan skor keterampilan berpikir kritis antara kelas eksperimen 1 yang diajar menggunakan model pembelajaran problem based learning dan kelas eksperimen 2 yang menggunakan model pembelajaran inkuiri terbimbing pada materi koloid kelas XI SMA Negeri Plus Provinsi Riau. Perbedaan tersebut dilihat dari nilai rata-rata keseluruhan dari indikator berpikir kritis dari kedua model yaitu nilai rata-rata keseluruhan model problem based learning 86,75 dan nilai rata-rata model inkuiri terbimbing sebesar 81,34 . Berdasarkan perbedaan nilai tersebut dapat dinyatakan bahwa model problem based learning lebih baik dalam meningkatkan keterampilan berpikir kritis siswa daripada model inkuiri terbimbing.
\end{abstract}

Kata kunci: keterampilan berpikir kritis, problem based learning, inkuiri terbimbing, koloid

\begin{abstract}
This research aimed at knowing the comparison between Problem Based Learning and guided inquiry model toward student critical thinking skill on chemistry subject especially on colloid lesson at the eleventh grade of MS of Plus State Senior High School, Riau Province. It was an experimental research with posttest only control group design. The samples of this research were the eleventh grade students of MS 1 as the first experiment group (using problem based learning) and the students of MS 3 as the second experiment group (using guided inquiry model). The technique of analyzing the data was t-test. The results showed a significant difference in the scores of critical thinking skills between Problem Based Learning model at the first experimental group, and guided inquiry model at the second experimental group on colloid lesson at the eleventh grade of Plus State Senior High School, Riau Province. The differences are seen from the overall score of the indicators of critical thinking from both model, i.e 86.75 for problem based learning treatment and 81.34 for guided inquiry model. Based on the score difference, it can be concluded that Problem Based Learning model was better than guided inquiry model in increasing student critical thinking skill.
\end{abstract}

Keywords: critical thinking skill, problem based learning, guided inquiry, colloid

DOI: https://doi.org/10.15575/jtk.v4i1.4329 


\section{PENDAHULUAN}

Pendidikan sangat berperan dalam kehidupan manusia. Seiring berkembangnya teknologi dan zaman, pendidikan pun mengalami perkembangan. Berkembangnya dunia pendidikan, mengundang berbagai permasalahan. Salah satu masalah yang terjadi saat ini adalah proses belajar di dalam kelas yang kurang melatih kemampuan berpikir kritis siswa, sehingga siswa cenderung menghafal materi yang disampaikan oleh guru yang mengakibatkan keterampilan siswa dalam berpikir kritis masih rendah. Siswa dapat mengembangkan keterampilan berpikirnya dengan baik dengan berlatih menggunakannya dalam konteks ilmu sains (Ningsyih dkk., 2016). Salah satu ilmu sains adalah kimia.

Belajar kimia merupakan cara mencari tahu dan memahami tentang alam secara sistematis, sehingga kimia tidak hanya diajarkan dengan sekedar memberikan pemahaman tentang pengertian-pengertian, fakta-fakta, konsep-konsep, prinsip-prinsip, tetapi juga melalui proses pencarian dengan tindakan nyata/inkuiri, sehingga pembelajaran dapat berpusat pada siswa (Fajariyah dkk., 2016). Namun, selama ini proses pembelajaran kimia masih berpusat pada guru. Siswa tampak pasif dalam kegiatan pembelajaran kimia, hal ini dikarenakan siswa hanya menerima apa yang diberikan oleh guru tanpa memahami maksudnya (Serfanda dkk., 2015). Akibatnya kurang mampu dalam membentuk sikap dan keterampilan berpikir kritis siswa.

Hasil penelitian Tim Survey IMSTEPJICA pada tahun 1999 di kota Bandung menunjukkan bahwa sejumlah kegiatan pembelajaran di sekolah yang menuntut kemampuan berpikir kritis dianggap masih rendah. Rendahnya hasil pembelajaran sains di sekolah juga dapat dilihat dari laporan PISA dan TIMSS. Menurut
PISA (Program for International Student Assessment) tahun 2012, Indonesia berada di urutan 64 dari 65 negara yang disurvei, artinya pembelajaran sains di Indonesia belum mampu meningkatkan keterampilan berpikir kritis siswa (Saputra dkk., 2016).

Keterampilan berpikir kritis merupakan cara bernalar yang dipopulerkan dalam bidang pendidikan sesuai dengan Peraturan Menteri Nomor 23 Tahun 2006 karena merupakan proses berpikir level tinggi (Higher Order Thinking) (Hanifah \& Agustina, 2012). Keterampilan berpikir kritis adalah proses mental yang mencakup kemampuan merumuskan masalah, memberikan dan menganalisis argumen, melakukan observasi, menyusun hipotesis, melakukan deduksi dan induksi, mengevaluasi, dan mengambil keputusan serta melaksanakan tindakan (Nursiti \& Barat, 2013).

Berpikir kritis menurut Ennis adalah kemampuan memberi alasan dan reflektif yang difokuskan pada apa yang diyakini dan dikerjakan (Kuswana, 2011). Berpikir kritis haruslah menggunakan alasan dan keyakinan yang kuat dalam melihat suatu hal dengan objektif, memisahkan masalah-masalah yang benar dan salah serta menyimpulkan suatu hasil yang dapat dijadikan pedoman untuk menentukan langkah dalam melakukan perubahan, dengan menggunakan kemampuan berpikir kritis memungkinkan kita untuk mengevaluasi argumen dan layak untuk penerimaan berdasarkan pikirannya.

Keterampilan berpikir kritis sangatlah diperlukan karena pada abad ke-21 dikenal sebagai abad pengetahuan yang memerlukan sumber daya manusia dengan kualitas tinggi dengan berbagai keterampilan, salah satunya adalah keterampilan berpikir kritis sehingga sumber daya manusia dapat bersaing dalam mengisi pasar kerja (Sugrah dkk., 2017). 
Keterampilan berpikir kritis juga amat penting bagi siswa bukan saja untuk menjawab berbagai tes akademik dengan akurat melainkan juga bekal life skill siswa agar dapat memiliki kecakapan dalam pengambilan keputusan. Siswa yang memiliki daya berpikir kritis biasanya memiliki kecenderungan memberikan komentar menyanggah gagasan dengan analisa yang logis, mampu memberikan perbandingan, memberikan saran dan kritik, berbeda pendapat, berpikir meluas atau berpikir mengerucut serta memiliki kecakapan dalam menyelesaikan masalah (Amri, 2015).

Namun berdasarkan hasil wawancara dengan guru bidang studi kimia di SMAN Plus Provinsi Riau menunjukkan bahwa keterampilan berpikir kritis siswa masih dianggap rendah. Hal ini dibuktikan dengan banyaknya siswa yang merasa kesulitan ketika diberikan pertanyaan yang menganalisis dan memerlukan keterampilan berpikir kritis. Siswa dapat menjawab pertanyaan guru mengenai pengertian, contoh, maupun sifat-sifat sesuai dengan apa yang dihafalkannya, namun ketika guru memberikan pertanyaan yang mengacu pada indikator-indikator keterampilan berpikir kritis yang lebih spesifik seperti menganalisis, memberikan penjelasan lebih lanjut dan menyimpulkan, sebagian besar siswa masih kesulitan menjawab pertanyaan tersebut. Siswa dapat menyebutkan sifat-sifat, tetapi tidak dapat menjelaskan bagaimana sifat tersebut dapat berkaitan dengan kejadian atau fenomena yang ditemukannya dalam kehidupan sehari-hari.

Materi sistem koloid dipilih dalam penelitan ini karena berkaitan dengan lingkungan sekitar siswa yang merupakan salah satu masalah yang perlu suatu penyelesaian dan penerapannya dapat digunakan dalam kehidupan sehari-hari, namun siswa menggangap bahwa materi koloid hanya bersifat hafalan, sehingga materi koloid sering diabaikan dan kemampuan siswa hanya sebatas apa yang mereka ingat. Hal ini menyebabkan kurangnya keterampilan berpikir kritis siswa (Wati dkk., 2014).

Menyikapi masalah yang timbul dalam pembelajaran kimia, diperlukan adanya perbaikan dalam pembelajaran yaitu dengan mengadakan perubahan atau perbaikan model pembelajaran yang tepat untuk meningkatkan keterampilan berpikir kritis siswa. Model pembelajaran yang dipandang mampu meningkatkan keterampilan berpikir kritis siswa yaitu model problem based learning dan inkuiri terbimbing (Diani dkk., 2016). Model pembelajaran problem based learning merupakan strategi pembelajaran yang inovatif, di mana pada model ini guru mendorong siswa dalam mengembangkan berbagai keterampilan, seperti keterampilan dalam pemecahan masalah, kreativitas dan keterampilan berpikir kritis (Safitri dkk., 2015). Sedangkan model inkuiri terbimbing merupakan bagian dari kegiatan pembelajaran dengan pendekatan kontekstual. Siswa diharapkan memperoleh pengetahuan dan keterampilan bukan hanya dari hasil mengingat fakta-fakta saja, melainkan juga dari menemukan sendiri, akibatnya dapat meningkatkan keterampilan berpikir kritis siswa dalam ranah kognitif (Ningsyih dkk., 2016).

Persamaan kedua model pembelajaran yakni sama-sama berorientasi pada masalah. Perbedaan keduanya adalah pada model pembelajaran berbasis masalah, orientasi masalahnya berada ditahap awal inti pembelajaran di mana peserta didik diberikan wacana seputar masalah yang berhubungan dengan dunia nyata. Pada model pembelajaran inkuiri terbimbing, orientasi masalahnya berada pada tahap inti pembelajaran di mana peserta didik

Jurnal Tadris Kimiya 4, 1 (Juni 2019): 21-32 
mengajukan pertanyaan-pertanyaan, kemudian mencari jawabannya dengan melakukan penyelidikan (Asnia dkk., 2017).

Sebelumnya terdapat beberapa penelitian yang meneliti tentang upaya peningkatan keterampilan berpikir kritis siswa. Di antaranya yaitu penelitian yang meningkatkan keterampilan berpikir kritis siswa dengan penerapan model problem based learning dalam pembelajaran geografi dengan hasil bahwa PBL dapat membuat pembelajaran geografi efektif dan efisien sehingga keterampilan berpikir kritis siswa meningkat (Herzon dkk., 2018). Penelitian lainnya ialah penelitian yang melihat peningkatan kemampuan berpikir kritis melalui model inkuiri terbimbing pada mata pelajaran fisika, didapatkan hasil bahwa bahwa ada pengaruh model pembelajaran inkuiri terbimbing terhadap kemampuan berpikir kritis siswa, dengan menggunakan model pembelajaran inkuiri terbimbing dapat lebih meningkatkan kemampuan berpikir kritis siswa (Nurmayani dkk., 2018). Berdasarkan penelitian relevan di atas penulis ingin melihat apakah terdapat perbedaan keterampilan berpikir kritis siswa yang diajarkan dengan model problem based learning dan model inkuiri terbimbing pada pembelajaran kimia khususnya pada materi koloid. Hal ini disebabkan kedua model sering diterapkan di sekolah, sehingga nantinya dalam pembelajaran dapat digunakan model yang lebih efektif.

Berdasarkan latar belakang yang telah dikemukakan, maka penelitian ini bertujuan untuk melihat perbedaan keterampilan berpikir siswa yang diajarkan dengan model problem based learning dan model inkuiri terbimbing. Penelitian ini dilakukan pada materi koloid. Setelah melakukan karakterisasi pada materi koloid maka indikator keterampilan berpikir kritis yang diukur pada penelitian ini adalah menganalisis argumen, menginduksi dan mempertimbangkan hasil induksi, serta mendefinisikan istilah dan mempertimbangkan suatu istilah.

\section{METODE PENELITIAN}

Penelitian ini merupakan jenis kuasi eksperimen yang dilakukan pada dua kelas di mana kelas eksperimen 1 mendapat perlakuan model problem based learning dan kelas eksperimen 2 mendapat perlakuan model inkuiri terbimbing. Desain penelitian ini adalah posttest only control group design. Penelitian ini dilakukan di SMA Negeri Plus Provinsi Riau pada bulan Mei 2018. Populasi terdiri dari 4 kelas yang berjumlah 90 orang. Sedangkan sampel terdiri dari dua kelas dengan total jumlah siswa 46 orang. Teknik pengambilan sampel menggunakan teknik simple random sampling. Teknik ini dilakukan setelah semua kelas diuji homogenitas dengan uji Bartlett. Uji homogenitas yang dilakukan peneliti diambil dari nilai ulangan harian pada materi kelarutan dan hasil kali kelarutan. Teknik pengumpulan data adalah tes dan dokumentasi. Tes berupa soal esai untuk mengukur keterampilan berpikir kritis siswa dengan terlebih dahulu dilakukan validasi isi dan validasi empiris kemudian dilihat reliabilitas, tingkat kesukaran, dan daya bedanya. Soal esai yang digunakan sebagai instrumen penelitian berjumlah 15 soal yang disesuaikan dengan indikator berpikir kritis yang digunakan. Pada penelitian ini peneliti menggunakan tiga indikator berpikir kritis menurut Ennis, yaitu menganalisis argumen, menginduksi dan mempertimbangkan hasil induksi, mendefinisikan istilah dan mempertimbangkan suatu istilah (Kartimi, 2013). Berdasarkan validasi empiris yang dilakukan diperoleh sebanyak 12 soal dinyatakan valid dan tiga soal tidak valid, sedangkan hasil analisis uji coba soal dengan menggunakan rumus metode alpha, diperoleh 
reliabilitas tes sebesar 0,926 dengan kriteria sangat tinggi. Dokumentasi digunakan untuk mendapatkan data-data dan hasil belajar siswa. Perbedaan langkah pembelajaran pada kelas eksperimen kesatu (problem based learning) dan kedua (inkuiri terbimbing) dapat dilihat pada Tabel 1.

Tabel 1. Perbedaan Tahapan Pembelajaran Problem Based Learning dan Inkuiri Terbimbing

\begin{tabular}{|l|c|}
\hline \multicolumn{2}{|c|}{ Tahapan Pembelajaran } \\
\hline $\begin{array}{c}\text { Problem Based } \\
\text { Learning }\end{array}$ & $\begin{array}{c}\text { Inkuiri } \\
\text { Terbimbing }\end{array}$ \\
\hline 1. Orientasi anak didik & 1.Menyajikan \\
kepada masalah & masalah awal \\
2.Mengorganisasikan & 2.Merumuskan \\
anak didik untuk & hipotesis \\
belajar & 3.Merancang \\
3. Membimbing & percobaan \\
penyelidikan & 4.Melaksanakan \\
individual maupun & percobaan \\
kelompok & 5.Menganalisis \\
4. Mengembangkan dan & data percobaan \\
menyajikan hasil karya & 6.Menarik \\
5. Menganalisis dan & kesimpulan \\
mengevaluasi proses & \\
pemecahan masalah & \\
\hline
\end{tabular}

Keterampilan berpikir kritis dianalisis dengan mengacu pada persamaan:

$$
\text { Nilai }=\frac{\text { Skor yang diperoleh }}{\text { skor maksimum }} \times 100
$$

\section{HASIL DAN PEMBAHASAN}

\subsection{Uji Homogenitas}

Penelitian ini membutuhan dua sampel kelas yang memiliki kemampuan homogen. Oleh karena itu perlu dilakukan tes uji homogenitas terlebih dahulu dari siswa yang terbagi dalam empat kelas. Uji homogenitas dilakukan berdasarkan data nilai siswa pada ulangan sebelumnya yaitu pada materi kelarutan dan hasil kali kelarutan. Uji homogenitas dilakukan dengan menggunakan uji Bartlet. Hasil analisis diperoleh $X_{\text {hitung }}$ sebesar 1,105 dan $X_{\text {tabel }}$ sebesar 7,815 dengan $\alpha=0,05$, karena $X_{\text {hitung }}<$ $X_{\text {tabel }}$ maka dapat disimpulkan bahwa sampel berasal dari populasi yang homogen. Hal ini berarti keempat kelompok sampel memiliki varians yang sama (homogen). Jadi, dapat disimpulkan bahwa ketika dilakukan pembelajaran dengan menggunakan model yang berbeda terhadap kedua sampel, apabila terjadi perbedaan keterampilan berpikir kritis siswa antara kedua sampel tersebut dikarenakan penggunaan model yang berbeda bukan karena kemampuan dasar yang berbeda.

\subsection{Analisis Butir Soal}

Sebelum penelitian dilakukan, peneliti terlebih dahulu perlu mengetahui soal tes yang digunakan sebagai instrumen tersebut baik atau tidak digunakan sebagai soal tes. Untuk itu, soal yang akan digunakan untuk posttest haruslah diuji terlebih dahulu kemudian dilakukan analisis butir soal. Hal ini bertujuan untuk melihat kriteria validitas, reliabilitas, tingkat kesukaran dan daya pembeda soal yang diinginkan, sehingga soal tersebut baik digunakan sebagai instrumen dalam penelitian ini. Jumlah soal yang diujikan sebanyak 15 soal dalam bentuk soal esai yang mana pengujiannya dilakukan di kelas XII MS 1 dengan jumlah peserta didik 20 orang.

Pada pengujian validitas, peneliti menggunakan validitas isi dan empiris, di mana pada validitas isi soal dikatakan valid apabila soal tersebut telah memenuhi sesuatu yang diukur (indikator). Berdasarkan hasil analisis, didapatkan bahwa 12 soal dinyatakan valid sedangkan tiga soal lainnya dinyatakan tidak valid. Berdasarkan hasil analisis reliabilitas soal, diperoleh reliabilitas tes sebesar 0,926 dengan kriteria sangat tinggi. 
Pengujian tingkat kesukaran soal sangat diperlukan dalam tes keterampilan berpikir kritis siswa. Hal ini bertujuan untuk mengetahui apakah soal tersebut termasuk dalam soal yang memiliki kriteria sukar maupun soal yang memiliki kriteria mudah, sehingga peneliti dapat menentukan soal yang layak digunakan dalam penelitian ini.

Berdasarkan hasil analisis tahap I diperoleh tingkat kesukaran soal dengan kriteria mudah sebanyak 33,33\%, kriteria sedang sebanyak $46,67 \%$ dan kriteria sulit sebanyak $20 \%$. Gambaran tingkat kesukaran soal yang termasuk kategori-kategori tersebut bisa dilihat pada Gambar 1.

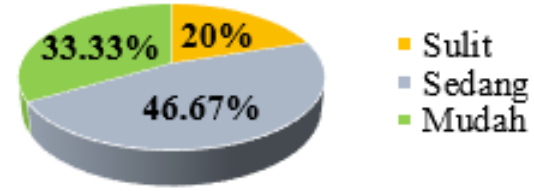

\section{Gambar 1. Diagram Tingkat Kesukaran Soal} Tes Tahap I

Berdasarkan hasil analisis tes tahap II, terdapat soal yang termasuk kategori soal sulit, sedang dan mudah. Pengujian tes tahap II menunjukkan soal dengan kriteria mudah persentasenya $30 \%$ dengan jumlah soal sebanyak tiga soal, kriteria sedang persentasenya $40 \%$ dengan jumlah soal sebanyak empat soal dan kriteria sulit persentasenya $30 \%$ dengan jumlah soal sebanyak tiga soal. Gambaran hasil tingkat kesukaran soal yang diperoleh pada tes tahap kedua bisa dilihat pada Gambar 2.

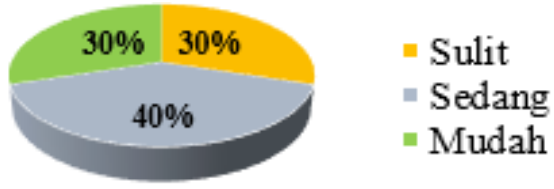

\section{Gambar 2. Diagram Tingkat Kesukaran Soal Tes Tahap II}

Pengujian daya pembeda soal bertujuan untuk mengetahui kesanggupan soal dalam membedakan siswa yang tergolong mampu dengan siswa yang tergolong kurang mampu atau lemah prestasinya. Daya pembeda soal pada tes tahap I diperoleh dari kategori daya pembeda sangat memuaskan sampai kategori daya pembeda soal yang sangat tidak memuaskan dan harus dibuang. Berdasarkan hasil analisis diperoleh $26,67 \%$ kriteria sangat tidak memuaskan, $6,67 \%$ kriteria tidak memuaskan, 53,33\% kriteria memuaskan dan $13,33 \%$ kriteria sangat memuaskan. Gambaran hasil daya pembeda soal yang diperoleh bisa dilihat pada Gambar 3.

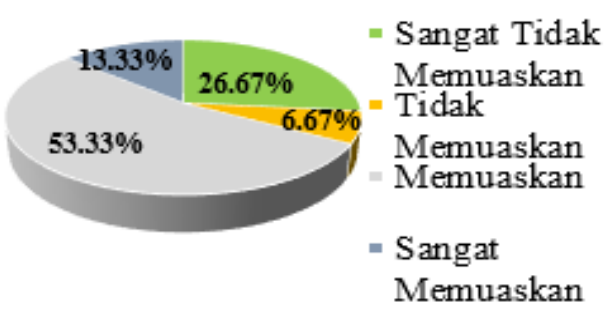

\section{Gambar 3. Diagram Daya Pembeda Soal Tes Tahap I}

Pada pengujian instrumen tahap kedua, nilai daya pembeda soal yang diperoleh, hanya yang digunakan adalah kriteria sangat memuaskan dan memuaskan. Daya pembeda soal yang termasuk kriteria soal sangat memuaskan terdapat pada soal nomor 14 dan 15 (sebesar 50\%), dan daya pembeda soal kriteria memuaskan terdapat pada nomor 1 , 2, 3, 8, 9, 10, 11 dan 12 (sebesar 80\%), sedangkan kriteria daya pembeda soal tidak memuaskan dan sangat tidak memuaskan tidak digunakan pada pengujian soal tahap II ini. Gambaran hasilnya bisa dilihat pada Gambar 4.

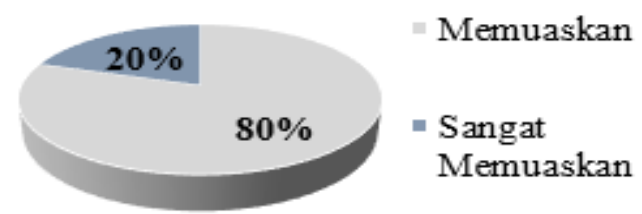

Gambar 4. Diagram Daya Pembeda Soal Tes Tahap II 
Berdasarkan hasil tersebut didapatkan soal yang daya pembedanya bisa digunakan sebagai instrumen penelitian sebanyak sepuluh soal, yakni tiga soal kategori tingkat kesukaran mudah, empat soal kategori tingkat kesukaran sedang, dan tiga soal kategori tingkat kesukaran sulit. Berdasarkan seluruh hasil analisis soal yang diuji cobakan, maka diperoleh sepuluh soal memenuhi empat kriteria yaitu validitas, reliabilitas, tingkat kesukaran dan daya pembedanya, sehingga dapat digunakan sebagai instrumen dalam penelitian ini. Dari sepuluh soal yang diperoleh, empat soal sesuai dengan indikator menganalisis argumen, tiga soal sesuai dengan indikator menginduksi dan mempertimbangkan hasil induksi, dan tiga soal sesuai dengan indikator menginduksi dan mempertimbangkan hasil induksi.

\subsection{Analisis Akhir}

Hasil analisis akhir data mendukung rumusan masalah yang diajukan, yaitu terdapat perbedaan keterampilan berpikir kritis siswa yang diajarkan dengan menggunakan model pembelajaran problem based learning dengan model pembelajaran inkuiri terbimbing pada materi koloid. Persentase nilai keterampilan berpikir kritis siswa terhadap materi koloid dapat dilihat pada Tabel 2.

Tabel 2. Persentase Nilai Keterampilan Berpikir Kritis Siswa

Persentase Nilai Keterampilan Berpikir Kritis

Indikator

\begin{tabular}{ccc} 
& Kelas & $\begin{array}{c}\text { Kelas } \\
\text { Eksperimen 2 }\end{array}$ \\
\cline { 2 - 3 } Menganalisis argumen & 80,98 \\
Eensperimen 1 & 89,95 & 78,26 \\
Mendefenisikan istilah dan mempertimbangkan suatu istilah & 75,00 & 84,78 \\
Rata-rata & 95,29 & $\mathbf{8 1 , 3 4}$ \\
\hline
\end{tabular}

Pada indikator berpikir kritis menganalisis argumen, besarnya keterampilan berpikir kritis siswa adalah 89,95\% pada kelas eksperimen 1 dan $80,98 \%$ pada kelas eksperimen 2 , dengan keduanya termasuk kategori baik sekali. Kedua model memiliki kategori keterampilan berpikir kritis yang baik sekali namun rata-rata keterampilan berpikir kritis siswa lebih tinggi pada model problem based learning. Hal ini sesuai dengan penelitian yang dilakukan oleh Diani dkk. (2016) yang menyataan bahwa hal tersebut dapat terjadi karena karakteristik model problem based learning yang dapat mendorong siswa untuk bepikir dan mempertanyakan secara kritis dan reflektif, sehingga siswa tidak langsung menyimpulkan namun mencoba untuk menemukan landasan argumen dan fakta-fakta yang mendukung alasan. Oleh karena itu siswa tidak hanya tahu namun juga memikirkan dan menganalisisnya terlebih dahulu.

Pada indikator berpikir kritis menginduksi dan mempertimbangkan hasil induksi, besarnya keterampilan berpikir kritis siswa adalah $75,00 \%$ pada kelas eksperimen 1 dengan kategori baik dan $78,26 \%$ pada kelas eksperimen 2 dengan kategori baik. Kedua model memiliki kategori yang baik, namun, apabila dilihat dari rata-rata indikator masingmasing, model inkuiri terbimbing lebih tinggi dibandingkan dengan model problem based learning. Hal ini sesuai dengan penelitian oleh Diani dkk. (2016) yang menyatakan bahwa di dalam model inkuiri terbimbing memiliki 
rangkaian pembelajaran yang menekankan pada perumusan hipotesis, diantaranya yaitu merumuskan dan menjawab hipotesis, sedangkan dalam model problem based learning tidak ada tahapan yang menekankan pada perumusan hipotesis. Oleh karena itulah model inkuiri terbimbing lebih baik pada indikator menginduksi dan mempertimbangkan hasil induksi dibandingkan model problem based learning.

Pada indikator berpikir kritis mendefinisikan istilah dan mempertimbangkan suatu istilah, besarnya keterampilan berpikir kritis siswa adalah 95,29\% pada kelas eksperimen 1 dan $84,78 \%$ pada kelas eksperimen 2, termasuk kategori baik sekali. Kedua model memiliki kategori keterampilan berpikir kritis yang baik sekali namun rata-rata keterampilan berpikir kritis siswa lebih tinggi pada model problem based learning. Hal ini sesuai dengan penelitian yang dilakukan oleh Diani dkk. (2016) yang menyatakan bahwa dalam problem based learning, permasalahan dan pertanyaan yang diberikan kepada siswa dibuat rumit atau kompleks sehingga tidak mempunyai jawaban yang pasti, oleh karena itu siswa mempunyai banyak penyelesaian dan seringkali bertentangan antar satu siswa dengan lainnya sehingga siswa dapat mempertimbangkan jawaban. Selain itu, siswa juga didorong untuk mengajukan dan pencarian jawaban dengan mandiri tanpa dibimbing dengan guru sedangkan dalam inkuiri terbimbing siswa lebih banyak dibimbing oleh guru sehingga siswa kurang mandiri dalam menjawab pertanyaan.

Berdasarkan penjelasan di atas kedua model pembelajaran terbukti dapat meningkatkan keterampilan berpikir kritis siswa. Hal ini dikarenakan model pembelajaran problem based learning yang diterapkan pada kelas eksperimen 1 merupakan model pembelajaran yang diawali dengan penyajian masalah yang berhubungan dengan realita atau kehidupan nyata, namun masih dalam konsep pembelajaran yang ditargetkan untuk dikuasai siswa, sehingga dapat menjadi stimulus dalam proses pembelajaran. Adapun tahapan pembelajaran $P B L$ yang diawali dengan orientasi pada masalah aktual, lalu dilanjutkan dengan mengorganisasi siswa dalam belajar, membimbing penyelidikan di dalam kelompok, mengembangkan dan menyajikan hasil karya, dan diakhiri dengan menganalisis dan mengevalusi proses pemecahan masalah, siswa secara individual maupun kelompok akan menganalisis masalah, mengidentifikasi dari inti permasalahan, mengidentifikasi apa yang harus dipelajari agar dapat memecahkan masalah, dan bekerja sama dengan sesama siswa untuk mengintegrasikan seluruh materi sehingga menghasilkan suatu kesimpulan dan pemecahan masalah (Sugrah dkk., 2017).

Kegiatan pembelajaran $P B L$ yang dilaksanakan dalam berkelompok memungkinkan siswa untuk menghadapi kompleksitas pendapat dengan tingkat perbedaan yang tinggi, sehingga membuat siswa melakukan analisis terhadap kebenaran dari pendapat-pendapat yang ada, memilih alternatif solusi terbaik dan memutuskan solusi terbaik untuk permasalahan yang diberikan. Oleh karena itu, secara tidak langsung melalui diskusi kelompok tersebut siswa dapat melatih keterampilan berpikir kritisnya.

Sedangkan pada kelas eksperimen 2 diterapkan model pembelajaran inkuiri terbimbing. Model pembelajaran inkuiri terbimbing melibatkan siswa berpikir secara aktif dan memberikan siswa kesempatan untuk mempelajari cara menemukan fakta, konsep dan prinsip melalui pengalamannya secara langsung. Jadi siswa tidak hanya belajar dengan membaca dan menghafal materi pelajarannya, tetapi juga dapat melatih dan mengembangkan keterampilan berpikir dan 
bersikap ilmiah (Mulyani dkk., 2015). Adapun enam langkah proses pembelajaran inkuiri yaitu orientasi, merumuskan masalah, merumuskan hipotesis, mengumpulkan data, menguji hipotesis, dan merumuskan kesimpulan. Berdasarkan langkah-langkah tersebut siswa didorong untuk mencari dan menemukan sendiri jawaban dari pertanyaan yang diberikan, sehingga siswa dapat menumbuhkan sikap percaya diri dan dapat meningkatkan kemampuan berpikir kritis nya dalam ranah kognitif (Ningsyih dkk., 2016).

Sintak dari kedua model ini melatih peserta didik dalam memecahkan masalah dan kecakapan untuk berpartisipasi dalam proses pembelajaran, sehingga menyebabkan siswa tidak hanya menerima pelajaran melalui penjelasan guru secara verbal, tetapi juga berperan dalam menemukan sendiri inti dari materi pelajaran itu. Seluruh aktivitas yang dilakukan siswa diarahkan untuk mencari dan menemukan sendiri jawaban dari suatu pertanyaan, sehingga dapat menumbuhkan sikap percaya diri siswa. Selain itu kedua model pembelajaran dapat mengembangkan kemampuan intelektual dari proses mental, akibatnya siswa tidak hanya dituntut agar menguasai materi, tetapi juga mengembangkan keterampilan berpikirnya (Puspita dkk., 2018). Perbedaan keterampilan berpikir kritis siswa kelas eksperimen I dan II berdasarkan indikator-indikator yang diukur dapat dilihat pada Gambar 5.

Berdasarkan Gambar 5 dapat dilihat bahwa nilai rata-rata pada indikator keterampilan berpikir kritis yang diperoleh pada kelas eksperimen 1 yang menggunakan model problem based learning lebih tinggi dibandingkan nilai rata-rata indikator pada kelas eksperimen 2 yang menggunakan model inkuiri terbimbing. Hal ini dapat diartikan bahwa model pembelajaran problem based learning lebih baik dalam meningkatkan keterampilan berpikir kritis siswa dibandingkan model inkuiri terbimbing. Hasil ini sesuai dengan penelitian yang dilakukan Puspita dkk. (2018) di mana terdapat perbedaan keterampilan berpikir kritis siswa menggunakan model inkuiri terbimbing dan $P B L$ dalam pembelajaran biologi, yaitu $P B L$ lebih meningkatkan keterampilan berpikir kritis siswa dibandingkan dengan model inkuiri terbimbing. Serta sesuai pula dengan penelitian yang dilakukan oleh Diani dkk. (2016) di mana model pembelajaran problem based learning memberikan pengaruh yang lebih baik daripada model pembelajaran inkuiri terbimbing terhadap keterampilan berpikir kritis siswa pada materi listrik dinamis.

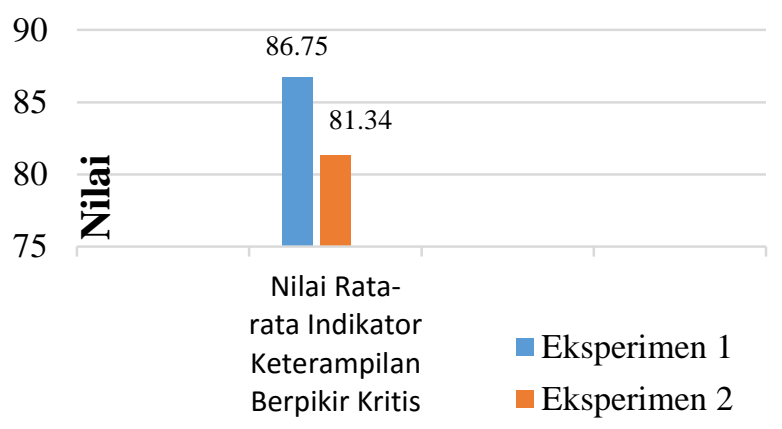

\section{Gambar 5. Perbandingan Keterampilan Berpikir Kritis Kelas Eksperimen 1 dan Kelas Eksperimen 2}

Model problem based learning lebih baik dalam meningkatkan keterampilan berpikir kritis siswa dibandingkan model inkuiri terbimbing karena proses pembelajaran problem based learning berpusat pada siswa sehingga siswa lebih aktif dalam proses pembelajaran. Pada proses pembelajaran yang menggunakan model problem based learning siswa dituntut membahas masalah-masalah yang autentik, sehingga siswa selalu dilatih berpikir bagaimana menemukan jalan keluar dari masalah-masalah tersebut. Latihanlatihan memecahkan masalah autentik ini menjadikan siswa selalu memberdayakan keterampilan berpikir kritis dan menjadikan 
siswa mempunyai keterampilan berpikir lebih tinggi sehingga mampu memecahkan masalah riil dan mengkaitkannya dengan tujuan pembelajaran yang ingin dicapai. Sedangkan pada model pembelajaran inkuiri terbimbing guru masih mendominasi proses pembelajaran, siswa tidak dilepas langsung seperti pada problem based learning. Siswa masih dibimbing dan diarahkan dalam mengidentifikasi masalah, membuat hipotesis, merancang percobaan, mengumpulkan data dan membuat kesimpulan. Sehingga siswa tidak mandiri dalam memecahkan masalah dan kurang mengeksplorasi keterampilan berpikir kritis yang dimilikinya (Puspita dkk., 2018).

\section{KESIMPULAN}

Berdasarkan hasil penelitian dan analisis data, dapat disimpulkan bahwa ada perbedaan terhadap keterampilan berpikir kritis siswa melalui model pembelajaran problem based learning dengan model pembelajaran inkuiri terbimbing pada materi koloid kelas XI SMAN Plus Provinsi Riau. Hal ini dapat dilihat dari nilai $t_{\text {hitung }}>t_{\text {tabel, }}$ di mana $t_{\text {hitung }}=2,34$ sedangkan nilai $t_{\text {tabel }}$ pada taraf signifikan $5 \%$ $=2,02$. Nilai rata-rata keseluruhan dari indikator berpikir kritis pada model problem based learning sebesar 86,75 dan nilai ratarata model inkuiri terbimbing sebesar 81,34. Berdasarkan perbedaan nilai tersebut dapat dinyatakan bahwa model problem based learning lebih baik dalam meningkatkan keterampilan berpikir kritis siswa daripada model inkuiri terbimbing, sehingga model problem based learning dapat digunakan oleh guru yang ingin meningkatkan keterampilan berpikir kritis siswanya. Untuk penelitian selanjutnya sebaiknya penelitian ini diteliti lebih lanjut dengan menggunakan indikator keterampilan berpikir kritis yang lainnya. 


\section{DAFTAR PUSTAKA}

Amri, S. (2015).Implementasi pembelajaran aktif dalam kurikulum 2013. Jakarta: Prestasi Pustakakarya.

Asnia., Sudding., \& Jusniar. (2017). Perbedaan Motivasi dan Hasil Belajar Peserta Didik Kelas XI IPA yang Dibelajarkan Model Pembelajaran Berbasis Masalah dengan Inkuiri Terbimbing di SMA Negeri 1 Majene pada Materi Pokok Sistem Koloid. Chemistry Education Review, 1(1), 15-25.

Diani, R., Saregar, A., \& Ifana, A. (2016). Perbandingan Model Pembelajaran Problem Based Learning dan Inkuiri Terbimbing terhadap Kemampuan Berpikir Kritis Peserta Didik. Jurnal Penelitian Pembelajaran Fisika (JP2F), 7(2), 147-155.

Fajariyah, N., Utami, B., \& Haryono. (2016). Penerapan Model Pembelajaran Inkuiri Terbimbing untuk Meningkatkan Kemampuan Berpikir Kritis dan Prestasi Belajar pada Materi Kelarutan dan Hasil Kali Kelarutan Siswa KELAS XI SMA AL ISLAM 1 Surakarta Tahun Ajaran 2014/2015. Jurnal Pendidikan Kimia (JPK), 5(2), 89-97.

Hanifah, N., \& Agustini, R. (2012). Peningkatan Self Efficacy dan Berpikir Kritis Melalui Penerapan Model Pembelajaran Inkuiri Materi Pokok Asam Basa Kelas XI SMAN 9 Surabaya. Unesa Journal of Chemical Education, 1(1), 27-33.

Herzon, H. H., Budijanto., \& Utomo, D. H. (2018). Pengaruh Problem Based Learning (PBL) terhadap Keterampilan Berpikir Kritis. Jurnal Pendidikan: Teori,
Perbandingan Model Problem Based Learning dan Inkuiri Terbimbing terhadap Keterampilan Berpikir Kritis Siswa

Penelitian, dan Pengembangan, 3(1), 4246.

Kartimi. (2013). Alat Ukur Keterampilan Berpikir Kritis Konsep Kimia untuk Siswa SMA. Yogyakarta: Deepublish.

Kuswana, W.S.. (2011). Taksonomi Berpikir. Bandung: PT. Remaja Rosdakarya.

Mulyani, N. K. S., Karyasa, I. W., \& Suardana, I. N. (2015). Komparasi Peningkatan Keterampilan Berpikir Kritis dan Kinerja Ilmiah Siswa yang Dibelajarkan dengan Model Project Based Learning dan Model Pembelajaran Inkuiri Terbimbing. e- Journal Program Pascasarjana, 5, 112.

Ningsyih, S., Junaidi, E., \& Al Idrus, S. W. (2016). Pengaruh Pembelajaran Praktikum Berbasis Inkuiri Terbimbing terhadap Kemampuan Berpikir Kritis dan Hasil Belajar Kimia Siswa. J. Pijar MIPA, 17(1), 55-59.

Nurmayani, L., Doyan, A., \& Verawati, N. N. S. P. (2018). Pengaruh Model Pembelajaran Inkuiri Terbimbing terhadap Kemampuan Berpikir Kritis Peserta Didik. Jurnal Pendidikan Fisika dan Teknologi, 4(1), 98-104.

Nursiti, N., \& Barat, W. L. J. (2013). Keterampilan Berpikir Kritis (Critical Thinking Skill) dalam Pembelajaran Ilmu Pengetahuan Sosial. Widyaiswara LPMP Jawa Barat. Retrieved from http://www.academia.edu/download/32 163452/Keterampilan_Berpikir_Kritis.doc $\mathrm{x}$.

Puspita, M. E., Setiadi, D., \& Raksun, A. (2018). Perbedaan Kemampuan Berpikir Kritis Peserta Didik dengan Menggunakan 
Model Inkuiri Terbimbing dan Problem Based Learning (PBL) dalam Pembelajaran Biologi pada Peserta Didik Kelas X SMAN 2 Gerung Tahun Ajaran 2016/2017. Prosiding Seminar Nasional Pendidikan Biologi, 242-248, Mataram: Universitas Mataram.

Safitri, E. H., Siahaan, J., \& Al Idrus, W. H. (2015). Studi Komparasi Hasil Belajar Kimia pada Materi Koloid Menggunakan Model Pembelajaran Berbasis Proyek dan Model Pembelajaran Berbasis Masalah Siswa Kelas XI IPA MAN 2 Mataram Tahun Ajaran 2013/2014. J. Pijar MIPA, 10(1), 52-56.

Saputra, Z. A. H., Yuanita, L., \& Ibrahim, M. (2016). Pengembangan Perangkat Pembelajaran Kimia Model Inkuiri untuk Meningkatkan Penguasaan Konsep dan Melatih Keterampilan berpikir Kritis Siswa SMA.Pendidikan Sains Pascasarjana Universitas Negeri Surabaya, 6(1), 1218-1223.

Serfanda, F. D., Mantini, S., \& Nurhayati, S. (2015). Komparasi Hasil Belajar dengan Model Problem Based Learning dan Inquiry. CiE, 4(2), 57-62.

Sugrah, N., Saraha, A. R., \& Djumat, H. H. (2017). Pengaruh Model Pembelajaran Problem Based Learning (PBL) terhadap Keterampilan Berpikir Kritis Peserta Didik Kelas XI IPA SMA Negeri 4 Kota Ternate. J. Saintifik@MIPA, 7(1),20-25.

Wati, R., Rusmanyah., \& Sholahuddin, A. (2014). Meningkatkan Kemampuan Berpikir Kritis dan Hasil Belajar Siswa Kelas XI IPA 2 SMA PGRI 4 Banjarmasin pada Konsep Sistem Koloid Melalui Model Problem Based Learning.
QUANTUM, Jurnal Inovasi Pendidikan Sains, 5(2), 20-31. 